University for Business and Technology in Kosovo

UBT Knowledge Center

Oct 28th, 2:00 PM - 3:30 PM

\title{
The effect of fine material amount on optimum water content of roller compacted concrete
}

\author{
Kubilay Akçaözoğlu \\ Nigde Ömer Halisdemir University, ozoglu@ohu.edu.tr \\ Bedrettin Menemencioğlu \\ Nigde Ömer Halisdemir University, bmenemencioglu42@gmail.com
}

Follow this and additional works at: https://knowledgecenter.ubt-uni.net/conference

Part of the Civil Engineering Commons

\section{Recommended Citation}

Akçaözoğlu, Kubilay and Menemencioğlu, Bedrettin, "The effect of fine material amount on optimum water content of roller compacted concrete" (2017). UBT International Conference. 45.

https://knowledgecenter.ubt-uni.net/conference/2017/all-events/45

This Event is brought to you for free and open access by the Publication and Journals at UBT Knowledge Center. It has been accepted for inclusion in UBT International Conference by an authorized administrator of UBT Knowledge Center. For more information, please contact knowledge.center@ubt-uni.net. 


\title{
The effect of fine material amount on optimum water content of roller compacted concrete
}

\author{
Kubilay Akçaözoğlu ${ }^{1}$, Bedrettin Menemencioğlu ${ }^{2}$ \\ ${ }^{1,2}$ Department of Civil Engineering, Faculty of Engineering, \\ Nigde Ömer Halisdemir University, Nigde 51245, Turkey \\ ozoglu@ohu.edu.tr1,bmenemencioglu42@gmail.com
}

\begin{abstract}
In this study the effect of fine material amount on the optimum water content of roller compacted concrete (RCC) was investigated. The fine aggregate was replaced with calcite which maximum particle size was $63 \mu$, in amount of $0 \%, 2 \%, 4 \%, 6 \%, 10 \%$ and $14 \%$ by weight of total aggregate. Six different mixtures were prepared in the study. The optimum water contents of the mixtures were determined by using modified proctor test. Optimum water content, maximum dry unit weight and maximum fresh unit weight of produced specimens were measured. Optimum water content of specimens decreased depending on increasing fine aggregate amount, however these values increased after a limit value. Maximum fresh and dry unit weights of specimens increased depending on increasing fine aggregate amount, however after a limit value the fresh and dry weights of specimens decreased.
\end{abstract}

Keywords: Roller compacted concrete, calcite, optimum water content of concrete, modified proctor test.

\section{Introduction}

Roller Compacted Concrete (RCC) is a special concrete that consolidated in the field using vibrating rollers [1,2]. The name of RCC is derived from the compacting of fresh concrete during the application $[3,4]$. In pavement application, it is placed without forms and not need finishing and also there are no dowels, tie bars, or steel reinforcement [5]. RCC pavements are stronger and more durable than Bituminous/Asphalt pavement, and no ruts are formed under high axle loads [2,6]. Compared to Asphalt pavement, RCC pavements have economic benefits. RCC needs less cementitious contents compared to typical Portland cement concrete pavements $[1,7,8]$. It is suitable for use in mass concretes due to low cement content [5].

The RCC has a zero slump and its properties are strongly dependent on the mixture proportions and compaction. For effective compaction, the RCC mixture must be dry enough to prevent sinking of the compaction equipment on the other hand it must be wet enough to adequate workability during the mixing and compaction of the RCC $[9,10]$.

The compressibility of RCC is affected by the mixture parameters such as free water content, cement and pozzolan content, fine aggregate amount, maximum aggregate size, aggregate granulometry and properties of the admixtures used. Free water content of the mixture is the most effective parameter in them. When the water content in the mixture reaches the optimum level, the maximum compressibility (maximum dry unit weight) can be achieved $[11,12]$.

Two approaches are used to determine the water ratio: Proctor test and Kangoo Vibration Hammer test [13]. Soil compaction approach is the most common method for determine the water ratio of RCC. This method involves determining optimum water content and maximum dry density of RCC mixtures according to proctor test [5]. In this investigation, the optimum 
water content of RCC mixtures was determined using the modified proctor test method. The effect of the amount of fine material on the optimum water content is also investigated.

\section{Materials}

\section{Material Properties}

In this investigation, Portland Cement CEM I $42.5 \mathrm{R}$ conforming to requirements of TS EN 197-1 [14] was used. The chemical compositions and physical properties of cement are given in Table 1 and Table 2.

Table 1. Chemical composition of PC

\begin{tabular}{lllllllllll}
\hline $\begin{array}{l}\text { Oxide } \\
(\%)\end{array}$ & $\mathrm{SiO}_{2}$ & $\mathrm{Al}_{2} \mathrm{O}_{3}$ & $\mathrm{Fe}_{2} \mathrm{O}_{3}$ & $\mathrm{CaO}$ & $\mathrm{MgO}$ & $\mathrm{Cl}$ & $\mathrm{SO}_{3}$ & $\mathrm{Na}_{2} \mathrm{O}$ & $\mathrm{K}_{2} \mathrm{O}$ & LOI \\
\hline Cem. & 20.3 & 5.35 & 3.15 & 62.1 & 1.50 & 0.02 & 3.30 & 0.65 & 0.95 & 2.01 \\
\hline
\end{tabular}

Table 2. Physical properties of PC

\begin{tabular}{ll}
\hline Properties & PC \\
\hline Specific weight $\left(\mathrm{g} / \mathrm{cm}^{3}\right)$ & 3.11 \\
Specific surface area (Blaine) $\left(\mathrm{cm}^{2} / \mathrm{g}\right)$ & 3450 \\
7-day Compressive strength $(\mathrm{MPa})$ & 39.0 \\
28-day Compressive strength $(\mathrm{MPa})$ & 46.2 \\
\hline
\end{tabular}

Crushed limestone aggregate with maximum size of $16 \mathrm{~mm}$ in accordance with TS $706 \mathrm{EN} 12620+\mathrm{A} 1$ [15] was used in the mixtures. The specific weights of fine aggregates and coarse aggregate at saturated surface dry condition measured according to TS EN 1097-6 [16] were 2.54 and $2.71 \mathrm{~g} / \mathrm{cm}^{3}$, the water absorption values of fine and coarse aggregate were 1.4 and $0.8 \%$, respectively. Calcite with maximum size of $63 \mu$ was used as a filler. The specific weight of calcite was $2.60 \mathrm{gr} / \mathrm{cm}^{3}$. The grading of calcite is presented in Figure 1. 


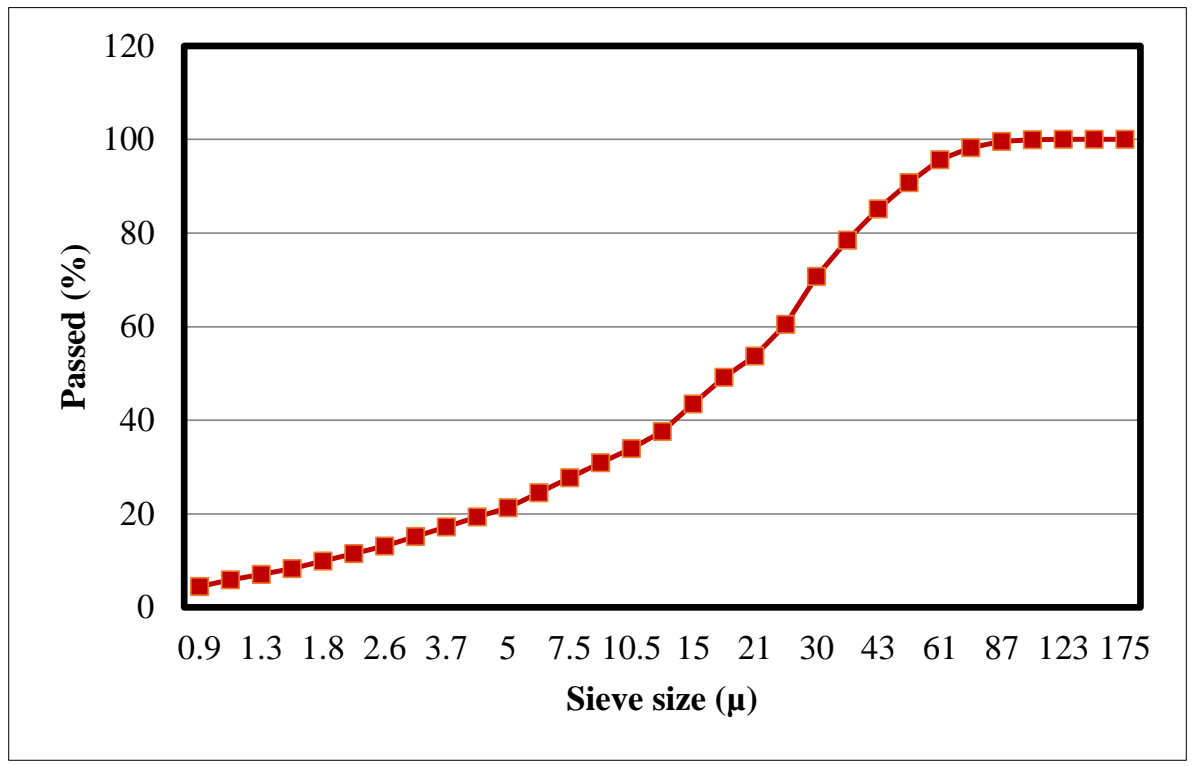

Figure 1. Calcite grading

For the preparation of control mixture, an aggregate granulometry according to the limit values as specified in TS 706 EN $12620+$ A1 [15] was determined and other mixtures were prepared by adding $2 \%, 4 \%, 6 \%, 10 \%$ and $14 \%$ calcite to the control mixture. Fine aggregate was reduced from the mixtures at the same rate of added calcite. Control mixture was called as RCC 1 and $2 \%, 4 \%, 6 \%, 10 \%$ and $14 \%$ calcite added mixtures were called as RCC2, RCC3, RCC4, RCC5 and RCC6, respectively. The grading of aggregates is presented in Figure 2 with the standard specification. 


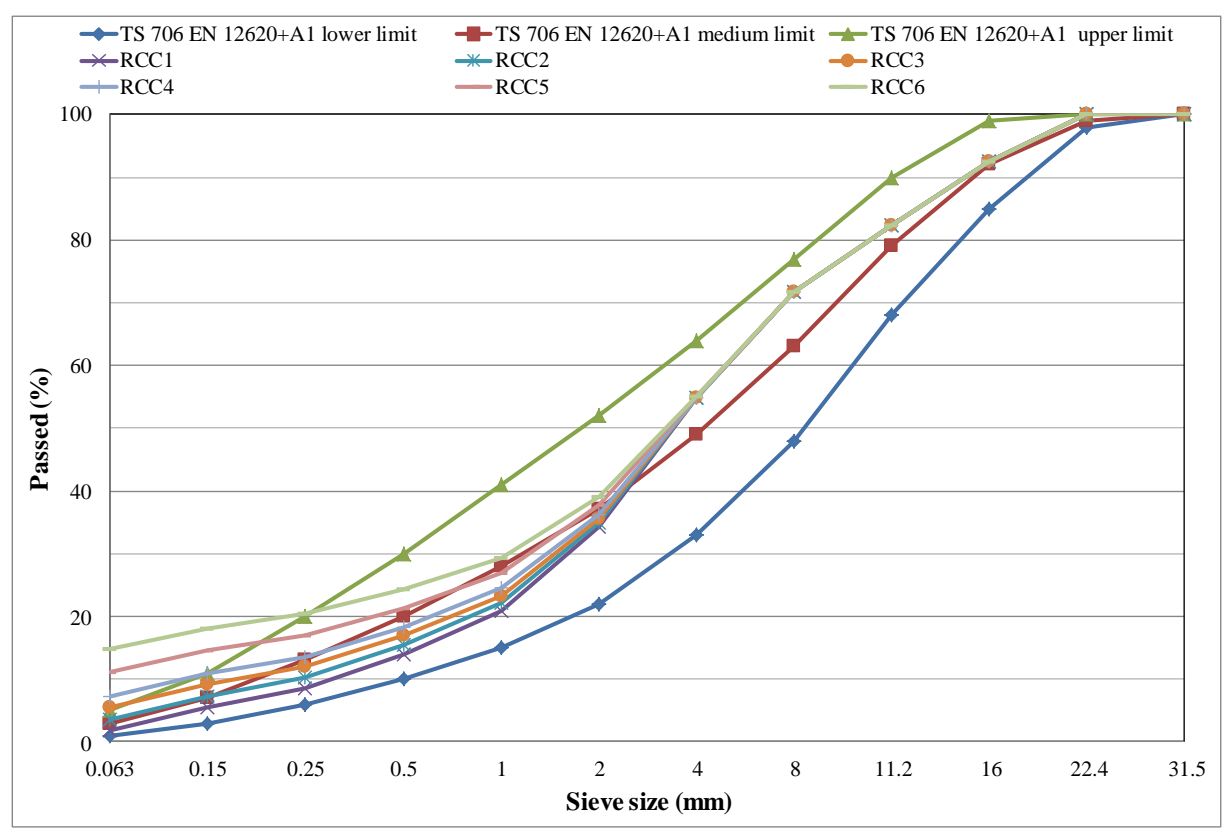

Figure 2. Aggregate grading with standart limit

\section{Determination of Optimum Water Content}

The modified proctor test method was used to determine the optimum water content of the mixtures in accordance with TS 1900-1 [17]. Firstly, all aggregates were dried for 24 hours at a temperature of $100 \pm 5{ }^{\circ} \mathrm{C}$ in order to precisely adjust the water quantities of the mixtures. Afterwards, optimum water content was determined by means of the automatic modification proctor test tool shown in Figure 3.

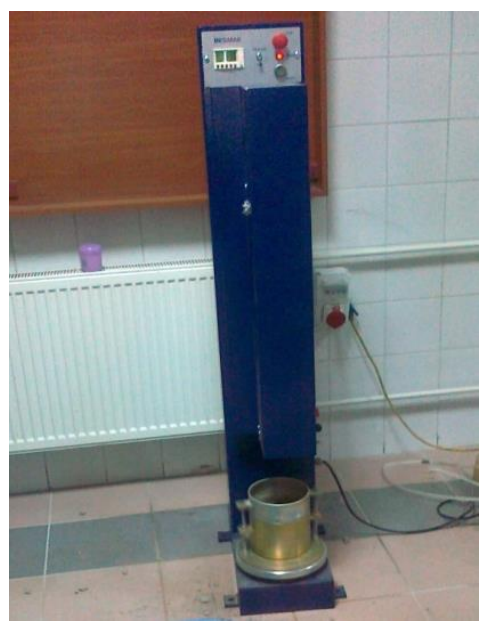

Figure 3. The automatic modification proctor test tool 
To determine the water content, samples were taken from the top and bottom of the cylindrical mold and placed in the oven and allowed to stand at $100 \pm 5^{\circ} \mathrm{C}$ for 24 hours for completely dry. The experiment was continued by increasing the water content of the samples. The water content $(\%)$ values of samples were calculated using equation (1).

$$
w(\%)=\frac{W_{2}-W_{3}}{W_{3}-W_{1}} \times 100
$$

Where:

$\begin{array}{ll}w & : \text { Water content }(\%), \\ W_{1} & : \text { Weight of mold, }(\mathrm{kg}), \\ W_{2} & : \text { Weight of fresh sample and mold }(\mathrm{kg}), \\ W_{3} & : \text { Weight of oven dry sample and mold }(\mathrm{kg}),\end{array}$

The fresh unit weights $\left(\mathrm{yn}_{\mathrm{n}}\right)$ and dry unit weights $(\mathrm{yk})$ of mixtures were calculated using equation (2) and (3), respectively.

$$
\gamma_{n}=\frac{W_{2}-W_{1}}{\mathrm{~V}}
$$

Where:

$\begin{array}{ll}\gamma_{n} & : \text { Fresh unit weight }\left(\mathrm{kg} / \mathrm{dm}^{3}\right), \\ W_{1} & : \text { Weight of mold, }(\mathrm{kg}), \\ W_{2} & : \text { Weight of fresh sample and mold }(\mathrm{kg}), \\ V & : \text { The volume of mold }\left(\mathrm{dm}^{3}\right),\end{array}$

$$
\gamma_{k}=\frac{\gamma_{n}}{1+w}
$$

Where:

$\begin{array}{ll}\gamma_{k} & : \text { Dry unit weight }\left(\mathrm{kg} / \mathrm{dm}^{3}\right), \\ \gamma_{n} & : \text { Fresh unit weight }\left(\mathrm{kg} / \mathrm{dm}^{3}\right), \\ w & \text { : Water content }(\%)\end{array}$

A similar water content-dry unit weight diagram as shown in Figure 4 was obtained and a second order equation was established. The optimum water content and maximum dry unit weights of the mixtures were determined using the obtained equation. 


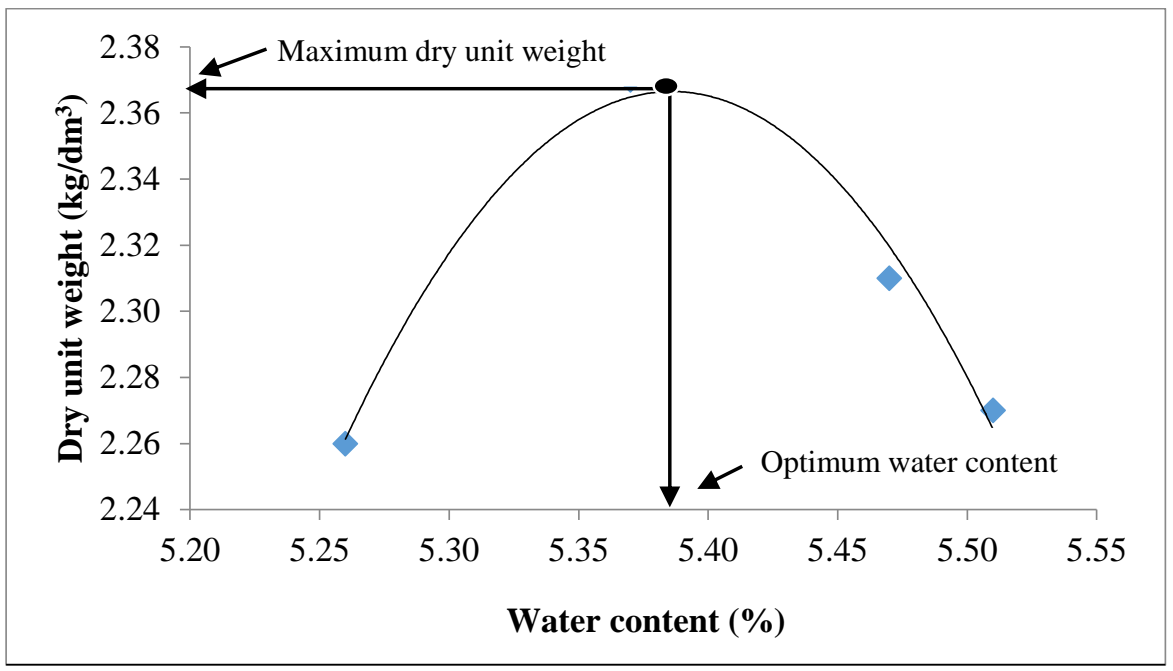

Figure 4. Water content - dry unit weight relation

In this study, optimum water contents were found for six RCC mixtures. The water content dry unit weight relation of these mixtures is given in Figures 5 - 10 .

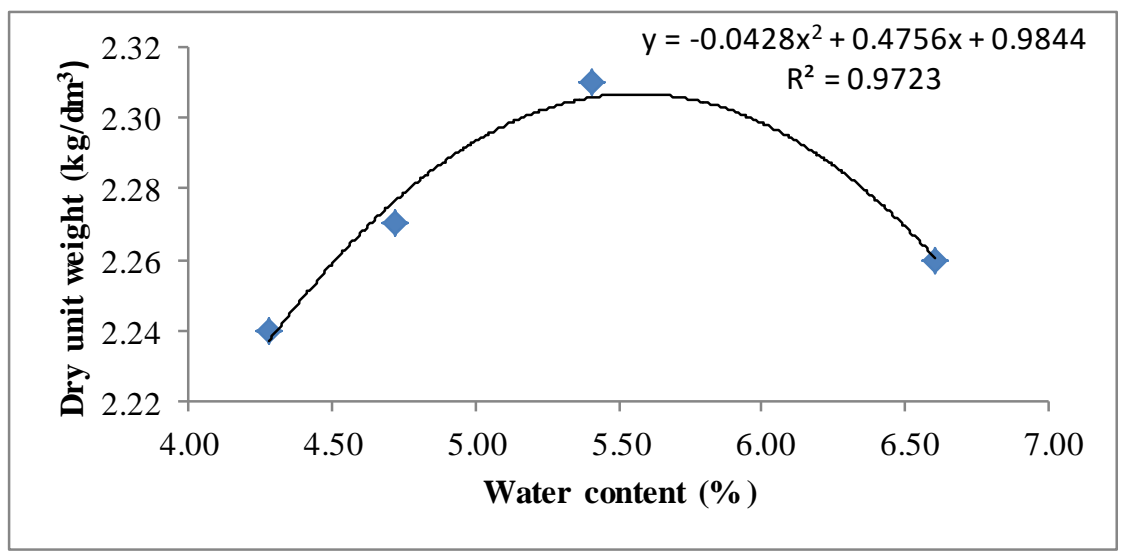

Figure 5. Water content - dry unit weight relation of RCC1 mixture (control) 


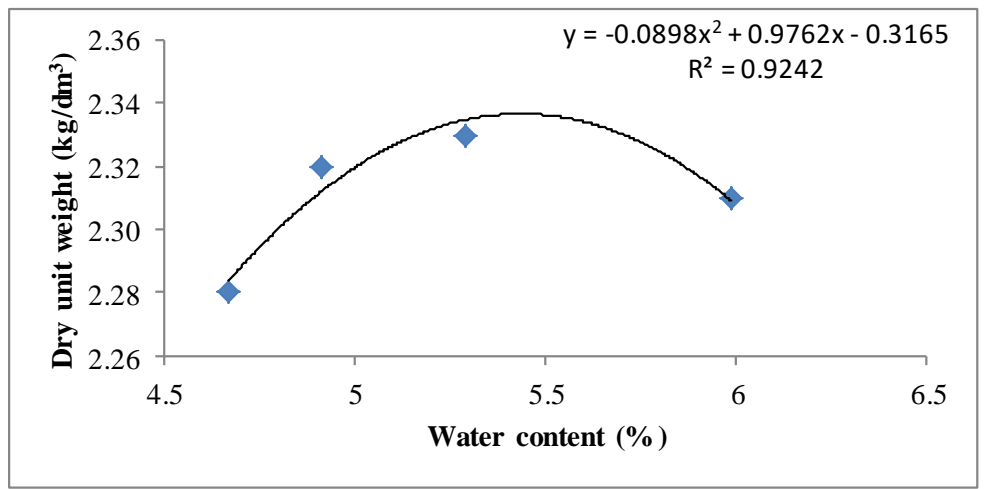

Figure 6. Water content - dry unit weight relation of RCC2 mixture

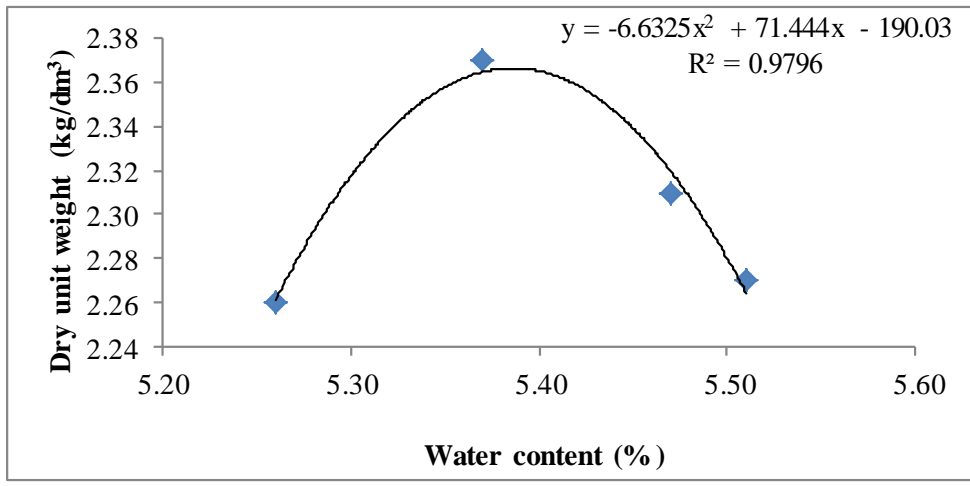

Figure 7. Water content - dry unit weight relation of RCC3 mixture

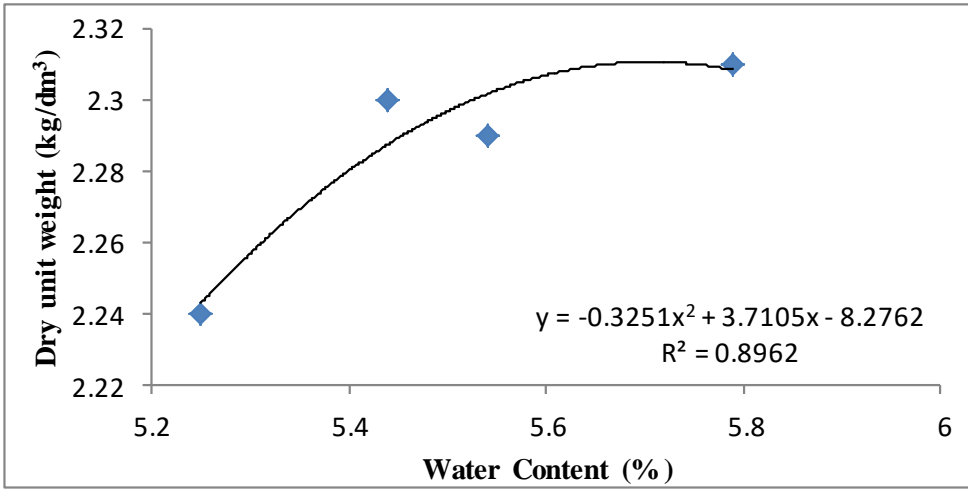

Figure 8. Water content - dry unit weight relation of RCC4 mixture 


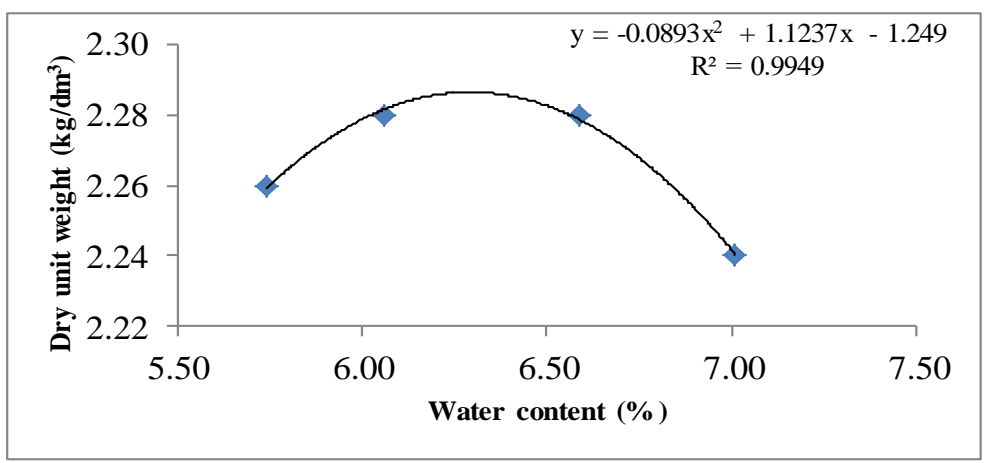

Figure 9. Water content - dry unit weight relation of RCC5 mixture

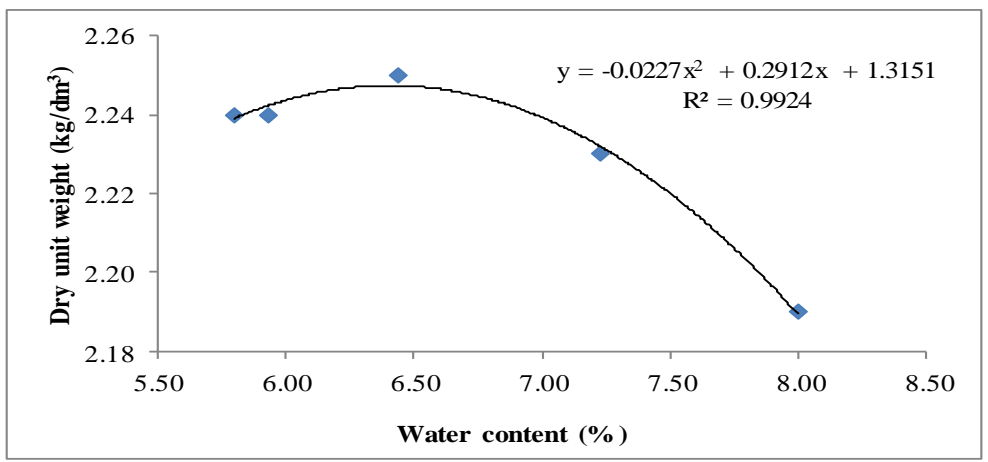

Figure 10. Water content - dry unit weight relation of RCC6 mixture

Optimum water contents were determined by using the relations indicated in the graphs and the ratio of water-dry material of each mixture was determined.

\section{Results and discussion}

The optimum water contents, maximum dry unit weights and maximum fresh unit weights for the mixtures are given in Table 3 .

Table 3. The optimum water contents, maximum dry unit weights and maximum fresh unit

\begin{tabular}{|c|c|c|c|}
\hline Mixture Adı & $\begin{array}{c}\text { Optimum } \\
\text { water } \\
(\mathbf{\%})\end{array}$ & $\begin{array}{c}\text { Maximum dry unit } \\
\text { weight } \\
\left(\mathbf{k g} / \mathbf{d m}^{\mathbf{3}}\right)\end{array}$ & $\begin{array}{c}\text { Maximum fresh unit } \\
\text { weight } \\
\left(\mathbf{k g} / \mathbf{d m}^{\mathbf{3}}\right)\end{array}$ \\
\hline RCC1 & 5,56 & 2,31 & 2,43 \\
\hline RCC2 & 5,44 & 2,34 & 2,46 \\
\hline RCC3 & 5,39 & 2,36 & 2,47 \\
\hline RCC4 & 5,71 & 2,31 & 2,44 \\
\hline RCC5 & 6,29 & 2,29 & 2,43 \\
\hline RCC6 & 6,41 & 2,25 & 2,39 \\
\hline
\end{tabular}


It is observed from Table 3 that compared with RCC1, optimum water content decreases in RCC2 and RCC3 mixtures however optimum water content increases in RCC4, RCC5 and RCC6 mixtures. The maximum dry unit weights and maximum fresh unit weight of the mixtures have similarly changed with increasing filler material. The maximum dry unit weights and maximum fresh unit weight of RCC2 and RCC3 mixtures increased. But these values decreased in the RCC4 mixture and return to the value of RCC1. This decline has also been observed in RCC5 and RCC6.

The situation shown in Table 3 can be explained as follows, the filler material, which is substituted for fine aggregate, better fills the interstices of the mixture and positively affects the compressibility. At a given compression energy, sufficient compression is achieved at a lower optimum water content. Thus, the maximum dry and fresh unit volume weight values are increased until the amount of filler material in the mixture reaches a certain level. This positive effect is explained by the reduction in the void fraction of the filler-substituted mixture. This positive effect comes to an end when the sufficient occupancy rate is reached. At this stage, increasing the amount of filler material, which has more specific surface than fine aggregate, causes an increase in the optimum water content of the mixture.

Approximate concrete composition for concrete mixture of a cubic meter was determined by using optimum water contents and is given in Table 4.

Table 4. Approximate concrete mix design for a cubic meter

\begin{tabular}{lcccccc}
\hline Mixture & $\begin{array}{c}\text { Cement } \\
\left(\mathbf{k g} / \mathbf{m}^{\mathbf{3}}\right)\end{array}$ & $\begin{array}{c}\text { Fine } \\
\mathbf{a g g r e g a t e} \\
\left(\mathbf{k g} / \mathbf{m}^{\mathbf{3}}\right)\end{array}$ & $\begin{array}{c}\text { Coarse } \\
\mathbf{a g g r e g a t e} \\
\left(\mathbf{k g} / \mathbf{m}^{\mathbf{3}}\right)\end{array}$ & $\begin{array}{c}\text { Calsite } \\
\mathbf{( \mathbf { k g } / \mathbf { m } ^ { 3 } )}\end{array}$ & $\begin{array}{c}\text { Water } \\
\mathbf{( k g / \mathbf { m } ^ { 3 } )}\end{array}$ & $\mathbf{w} / \mathbf{c}$ \\
\hline RCC1 & 340 & 1082 & 894 & 0 & 129 & 0,38 \\
RCC2 & 340 & 1045 & 898 & 40 & 126 & 0,37 \\
RCC3 & 340 & 1008 & 898 & 79 & 126 & 0,37 \\
RCC4 & 340 & 961 & 892 & 118 & 133 & 0,39 \\
RCC5 & 335 & 871 & 882 & 195 & 144 & 0,43 \\
RCC6 & 335 & 792 & 880 & 272 & 147 & 0,44 \\
\hline
\end{tabular}

\section{Conclusions}

According to test results, it was seem that the optimum water content of RCC samples ranged between $5.39 \%$ and $6.41 \%$. The optimum water content of RCC mixtures decreased in the presence of $2 \%$ and $4 \%$ filler material, while the optimum water content increased in the presence of $6 \%, 10 \%$ and $14 \%$ filler material. The maximum dry and freshunit weights values are changed inversely to the optimum water content.

The compressibility of the concrete is positively affected by the increase of the amount of filler material in the mixtures, and at constant compression energy, this effect achieves a sufficient compression value with lower optimum water content. This positive effect continued until the sufficient filling ratio of the mixing aggregate was reached. This positive effect has been come to an end by increasing the filler material and caused an increase in the optimum water content. 


\section{References}

1. ACI Committee 325, State-of-the-Art Report On Roller-Compacted Concrete Pavements. ACI 325.10R-95, American Concrete Institute, 2000.

2. Rao, K. S., Sravana, P., Rao, T. C.: Abrasion Resistance and Mechanical Properties of Roller Compacted Concrete with GGBS. Construction and Building Materials. 114 (2016) 925-933

3. Karakurt, C., Pektaş, M. R.: Properties of Roller Compacted Concretes Produced with Fly Ash and Ground Granulated Blast Furnace Slag. Bilecik Seyh Edebali University Journal of Science, 2 (2) (2015) 1-8

4. Atiş, C. D.: Properties of Roller Compacted Concretes with Fly Ash. Turkish Journal of Engineering and Environmental Sciences. 25 (2001) 503-515

5. Chhorn, C., Hong, S. J., Lee, S. W.: A Study on Performance of Roller-Compacted Concrete for Pavement. Construction and Building Materials. 153 (2017) 535-543

6. Naik, T. R., Chun, Y. M., Kraus, R. N., Singh, S.S., Pennock, L. L. C., Ramme, B.W.: Strength and Durability of Roller-Compacted HVFA Concrete Pavements. Practice Periodical on Structural Design and Construction 6 (4) (2001) 154-165

7. LaHucik, J., Dahal, S., Roesler, J., Amirkhanian, A. N.: Mechanical Properties of RollerCompacted Concrete with Macro-Fibers. Construction and Building Materials. 135 (2017) 440-446

8. Harrington, D., Abdo, F., Adaska, W., Hazaree, C. V., Ceylan, H., Bektas, F.: Guide for Roller-Compacted Concrete Pavements. National Concrete Pavement Technology Center. Technical Report. Iowa, 2010.

9. Mehta, P. K., Monteiro P. J. M.: Concrete: Microstructure, Properties, and Materials. 4th ed. Mc Graw Hill Education (2014)

10. Omran, A., Harbec, D., Tagnit-Hamou, A., Gagne, R.: Production of Roller-Compacted Concrete Using Glass Powder: Field Study. Construction and Building Materials. 133 (2017) 450-458

11. ACI Committee 309, Compaction of Roller-Compacted Concrete, ACI 309.5R-00, American Concrete Institute, 2000.

12. ACI Committee 207, Roller Compacted Mass Concrete, ACI 207.5R, American Concrete Institute, 1988.

13. Jofre, C.: The Use of Roller Compacted Concrete for Roads. PIARC Technical Committee on Concrete Roads (1993)

14. TS EN 197-1:2012 Cement - Part 1: Composition, Specification and Conformity Criteria for Common Cements. Turkish Standard Institution. Ankara.

15. TS 706 EN 12620+A1:2009 Aggregates for Concrete. Turkish Standard Institution. Ankara.

16. TS EN 1097-6:2015 Tests for Mechanical and Physical Properties of Aggregates - Part 6: Determination of Particle Density and Water Absorption. Turkish Standard Institution. Ankara.

17. TS 1900-1:2007 Methods of Testing Soils for Civil Engineering Purposes in the Laboratory. Turkish Standard Institution. Ankara. 